\title{
Theoretical and methodological framework for the analysis of international forest political processes by stakeholders' perceptions at national level
}

\author{
Lenka Halušková*, Zuzana Dobšinská, Jaroslav Šálka \\ Technical University in Zvolen, Faculty of Forestry, T. G. Masaryka 24, SK - 96001 Zvolen, Slovak Republic
}

\begin{abstract}
Forests cover about $30 \%$ of the world's land area and provide people and nature with essential ecosystem services and goods. Despite their importance, forests continue to be degraded. A variety of international forest governance and policy arrangements have developed to foster protection and sustainability of forests. However, number of studies point to nonexistence of a global forest policy regime per se, and growing institutional fragmentation of forest governance arrangements. In line with continuing priority of national sovereignty in the international regulation of forest policy, the role of domestic policies, mainly domestic forest policy actors, is considered central to international forest governance analysis by many researchers. The paper aimed to set the framework for the international forest policy analysis by domestic forestry stakeholders' perceptions. The dimensions of Policy Arrangements Approach modified for purpose of meeting the nature of research, serve as theoretical foundations. In the first part, the paper aim to define dimensions theoretically. In the second part, specific international forest-focused political processes are described through adapted dimensions. The two steps serve as the basis for research to be subsequently applied in selected European countries.
\end{abstract}

Key words: international forest political processes; adapted Policy Arrangements Approach; international forest policy applied research

Editor: Vilém Jarský

\section{Introduction}

The 1980s experienced growing concern of international community about the destruction of tropical forests due to over-exploitation for timber production, cattle ranching and agriculture shifting, as well as loss and degradation of temperate and boreal forests due to poor forest management and pollution caused by industrial development (Sotirovetal. 2020). Forests are home to $70 \%$ of the known terrestrial plant and animal species. Furthermore, they are critical factors for climate change as sources and sinks of $\mathrm{CO}_{2}$ on one side, and their vulnerability to climate change on the other (Marcos-Martinez et al. 2019). All people depend upon forests and their biodiversity, some more than others. Forests provide more than 86 million green jobs and support the livelihoods of many people. An estimated 880 million people worldwide spend part of their time collecting fuelwood or producing charcoal (FAO 2020). Despite their importance, forests continue to be degraded. The problem of forest degradation and deforestation is not limited to certain countries but is globalized (Henry \& Tysiachniouk 2018).
Since 1990s, the global society has accepted sustainable development concept as a vision for global, regional, national, and local communities level. The non-legally binding Forest Principles were adopted at the United Nations Conference on Environment and Development (UNCED) in Rio de Janeiro in 1992, as well as the Chapter 11 of Agenda 21 on combating deforestation (Park \& Lee 2019). The outcome of deliberations in Rio was a signal of global consensus on the importance of forests and the need of their maintenance for future generations, as well as the willingness of international community to support national efforts (Rayner et al. 2010). In contrast to positive turn of global community to forests issues, the attempts to adopt a forest legally-binding convention had failed. While the developed countries had argued for the forests convention, the developing countries responded by arguing that such a convention would transgress the sovereignty of states over their natural resources, moreover placing condition of substantial payment for conservation by developed countries (Humphreys 2003). 
After the global forest convention failure, in early 1990s forest management sustainability certification emerged as a non-state market driven, private governance of forests (Henry \& Tysiachniouk 2018). The main tools represented a voluntary or non-governmental organisations' (NGOs) pressure for eco-labelling in line with principles, criteria and indicator (C\&I), and Sustainable Forest Management (SFM) standards (Sotirov et al. 2020). However, companies choose to participate in or to reject the certification. While certification schemes are global, their effectiveness depend on the interaction with institutions and policy at the national and local levels. Henry \& Tysiachniouk (2018) note studies on international forest policy mostly focus on the features of transnational standards and rules, thus under-represent the importance of local perceptions and practices.

The 2030 Agenda for Sustainable Development adopted in 2015 defined integrative approach to natural resource management, including forests (Wolfslehner et al. 2020). Forests contribute to nearly all of the agreed Goals (Sotirov et al. 2020). The Sustainable Development Goal 15 relates directly to forests, while recognising the interactions between forest, water and biodiversity (Wolfslehner et al. 2020). In context of the United Nations (UN) Sustainable Development Goals (SDGs), the UN Strategic Plan for Forests was adopted by states and intergovernmental organisations (IGOs) in 2017 (Sotirov et al. 2020).

Sotirov et al. (2020) claim that international forest governance and policy arrangements represent ,sets of implicit and explicit principles, norms, rules, and decision making procedures around which actors' expectations converge in a given area of international relations" (Krasner 1982, p. 186). The definition was originally used by Standford scholar Stephen Krasner to define „international regimes“ as such (Rayner et al. 2010). The term „international“ refers to any type of forest and forest-related governance and political activity among any type of actors going beyond national boundaries (Sotirov et al. 2020). Giessen (2013) goes beyond these definitions, posing a question whether international forest regime actually exists. The current literature provides different answers to this question. The group of regime theorists define the individual features of regime as principles standing for beliefs of facts, norms for standards of behaviour in terms of rights and obligations, rules for prescriptions for action and decision-making procedures for prevailing practices to collective action (Rayner et al. 2010; Humphreys 2009; and others). Regime theorists argue that international regime requires a multilateral legal framework such as an organization or treaty. Non-regime theory representatives stress a notion that a particular consensus in the area of international forests existed not to have a regime, but to establish hollow weak institutions instead (Dimitrov 2005). Most of the literature suggests that international forest regime exists as it meets its key elements, and this understanding has been further developed into the concept of an international forest regime complex (Giessen 2013; Glück et al. 2010; Humphreys 2009; Logmani et al. 2017; Rayner et al. 2010; Singer \& Giessen 2017). In this line, Howlett et al. (2010) suggest term a "regime complex" rather than a „regime" per se. This concept integrates formal legal governance and other governance arrangements, and helps to bridge the divide between two interpretations of forest cooperation. Some scientists avoid regime terminology and refer to the broader concept of global forest governance, considering explicitly the private, non-state actors and institutions (Giessen 2013).

At the international level, forest policy suffers from difficulties in securing agreement on one side, and a lack of implementation on the other. Top-down attempts for the creation of a new-treaty based international regime have failed. International forest regime complex is composed of multiple agreements, some with explicit focus on forests, and some addressing forest-related issues indirectly. Neither the international regime complex itself nor the governance framework can be considered as designed. They are better described as self-organising outcomes of a variety of separate initiatives (Howlett et al. 2010).

In line with recent research and studies on international level of forest policy, we conclude the trends as follows: 1 . in the absence of a legally binding agreement, the forest policy is described as multi-centric and fragmented, 2. governance in the sense of non-state actors' participation, diffusion of authority and absence of topdown hierarchical regulation is suitable to describe forest policy arrangements in a wider concern. Despite the fact the term ,international" mostly concerns the global level of forest policy, Edwards and Kleinschmit (2013) claim the similar trends apply for the case of Europe. The responsibility for forest management within Europe rests with each nation state. There has been no legally binding common forest policy set up, whether in the panEuropean, neither in the European Union (EU) level. However, several initiatives and policy documents of voluntary type have been in place within international context of forest policy, i.e. Forest Principles, Chapter 11 of Agenda 21, United Nations Forum on Forests (UNFF), United Nations Non-Legally Binding Instrument on All Types of Forests, New York Declaration on Forests, UN Strategic Plan for Forests, Sustainable Forest Management criteria and indicator (SFM C\&I) regional processes and forest management certification schemes at the global scale (Sotirov et al. 2020), and National Forest Programmes (NFPs) or the EU Forest Strategy at the European one (Edwards \& Kleinschmit 2013).

Literature points out the role of domestic policies, especially domestic actors as the central to international forest policy analysis (Krott et al. 2013; Singer \& Giessen 2017; Faggin \& Behagel 2017; Sotirov \& Storch 2018). This argument is based on the concept of national sovereignty, which remains to have priority in the international 
regulation of forest policy. The premise that international forest policy cannot be effective without the resources and support of key domestic actors is the starting point. Domestic actors can be state and non-state, coming from different policy sectors, environmental, social or business NGOs, forest owners, academia, etc. In accordance with the theory of multilevel governance, domestic actors can operate at the national, sub-national and local levels (Bache \& Flinders 2004). Domestic actors select individual components from the international policy level and adapt them to national conditions in compliance with their own interests and opinions, and subsequently influence the domestic agenda, for example through discourse (Singer \& Giessen 2017). Actors and their coalitions will support policy outputs when they resonate with their policy core beliefs (Hall 2006).

Translations between the international and national level of forest policy are discussed as complex interactions (Faggin \& Behagel 2017). Specific studies showing empirically how a set of rules, norms and ideas of various international forest policy arrangements are translated to a domestic context, are missing for many countries (Arts et al. 2010; Singer \& Giessen 2017; Faggin \& Behagel 2017; Aggestam \& Pülzl 2020). To fill this research gap, our research will focus on the analysis of domestic stakeholders' perceptions on how international forest policy documents and processes are reflected at national level, either in policy documents, legislation, and forestry institutions as such. The research will be conducted by using document analysis complemented by stakeholders' interviews.

The objective of the paper is to propose a theoretical and methodological framework for analysing domestic stakeholders' perceptions, using the modified Policy Arrangements Approach (PAA) as the theoretical foundation. The objective of the paper is divided in two subobjectives: 1 . to define PAA dimensions theoretically, 2. to describe the international political processes using defined dimensions.

The framework can be subsequently applied for research in different European countries, considering their similarities and diferencies in forestry history and current forest policy. The results will open the space for comparison of analysed countries.

\section{Theoretical background}

The "Policy Arrangement Approach" (PAA) was selected as the basis for our forest political processes analysis framework, as it defines the most significant policy dimensions and thus offers a comprehensive picture of the political process (Arts \& Leroy 2006). In accordance with the nature of research, we recommend to add the dimension of level interactions to the PAA. As Weber pointed out, existing theories can be combined in order to better analyse selected research problem. This approach is widespread in social and political sciences (Weber 2012). Interactions will be studied in the sense of to what extent the international and national levels of forest policy interact, the way how domestic forestry stakeholders perceive this interaction, and the direction of its flow. Some of the many theoretical approaches to research on interactions in forest policy are summarized below. We prefer the two-way approach designed by Börzel (2002), as it focuses not only on the issue of implementation, but also on whether national policies try to upload their ideas to international level, and if so, to what extent.

Policy arrangement is defined as "the temporary stabilisation of the content and organisation of a particular policy domain at a certain policy level” (Arts \& Leroy 2006, p. 13). Consequently, they distinguish four dimensions of policy arrangements. For purpose of our analysis, the modified PAA consist of five dimensions as follows:

- actors involved in the policy domain and their coalitions,

- the division of power (resources) and influence (policy outcomes determination) between the actors,

- the rules of the game in terms of formal and informal rules and routine,

- the policy discourses and programmes, including norms and values (Arts \& Leroy \& van Tatenhove 2006),

- interactions between international and national level of forest policy (added by the authors).

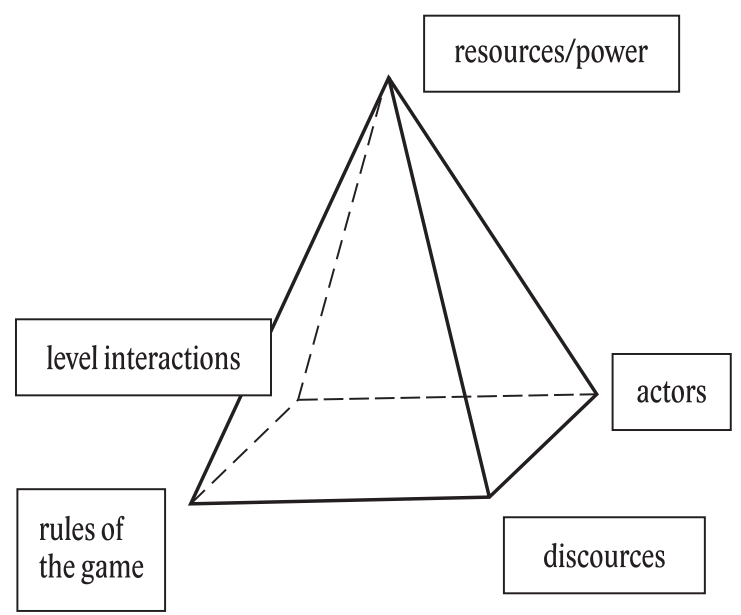

Fig. 1. Adapted Policy Arrangements Approach dimensions. Source: Liefferink (2006) modified by authors.

In the actor-oriented institutionalism, Scharpf (2000) considers actor to be the major factor in policy analysis, and defines it as "acting entity that is involved in the formulation and implementation of a policy" (Schneider 2009, p. 192). The actor's action needs to be examined in the light of a given policy area. Actors can be individual and group. In group he distinguishes: a.) internally coordinated individuals, b.) corporate actors acting in the form of the organization as a whole (state associations, state administrations) (Krott et al. 2013). 
Schusser et al. (2016, p. 82) defines actor in the sphere of forest policy as "any entity that has a distinct interest and the ability to influence a policy”. Weber (2012) puts the actor at the centre of his theory of power. Power is defined as the possibility for an actor to be in a position to carry out his will in a social relationship despite resistance, regardless of the origin of that possibility. An actor can do something concrete through power. Within the trends of forest governance, some scholars identify the power of important political actors as a decisive factor to explain them (Agrawal \& Chharte \& Hardin 2008; Giessen \& Kleinschmit \& Böcher 2009; Krott et al. 2013). Furthermore, literature points out a lack of theory-based, empirically applicable, analytical frameworks in forest policy research focusing on actors' power (Schusser et al. 2015).

Maier et al. (2014) claim participatory elements incorporation to decision-making processes has become a feature of post-modern governance, forestry sector not excluded. The participation literature and research is mainly focused on non-state actors participation in terms of moving trends to make steering mechanisms in policies more inclusive, by taking into account broader societal demands.

The actor has certain interests in the system and may also have the ability to influence directly or indirectly this system. In other words, the behaviour of the actors is motivated by their interests. The actor pursues a certain goal (Krott et al. 2013). Krott (2005, p. 8) defines interests as "based on action orientation, adhered to by individuals or groups, and they designate the benefits the individual or group can receive from certain object, such as a forest". The interests of actors in forestry arise from various ideas about forest management and use of forest, and are divided into economic, ecological and social (Šálka et al. 2017).

The actors tend to group together in coalitions in accordance with their common interests. Sabatier (1998) developed advocacy coalition framework defining values and shared beliefs as determining for actors to group in coalitions. Giessen (2011) clarifies the categories of beliefs and interests are not separated, but they exist side by side.

The rules of game set a domain. Rules define the way by which the game should be played and within which boundaries. Formal rules of game show the mechanisms of issues framing, agendas formulating, and decisionmaking. They provide the information about which procedures and division of competitions are in place within the steering mechanisms (Arts \& Buizer 2009). Informal rules of game represent mechanisms that are not formally anchored, rather based on customs.

Role of discourse in governance studies is explained by the shift of mechanism of political coordination. Top down hierarchical regulation has been replaced by new modes of governance, including societal and private actors (Kleinschmit \& Böcher \& Giessen 2009). Hajer
(1995, p. 44) defines discourse as ,an ensemble of ideas, concepts and categorizations that are produced, reproduced, and transformed in a particular set of practices and through which meaning is given to physical and social realities". Crucial for discourse theory is not whether such discourse produces true or false, but the fact it exists. Long duration is typical for discourses. Nevertheless, it does not exclude discoursive change, i.e. by influential actors whose interventions resonate in the media, science and politics (Arts et al. 2010). The PAA defines discourses as interpretative schemes ranging from formal policy concepts to popular narratives and story lines giving a meaning to policy domain (Dryzek 1997). Discourse analysis is a way to examine how international forest processes influence domestic policy, as norms and discourses can influence domestic actors' behaviour directly by setting social norms. Understanding the interactions of international and domestic levels of governance implies understanding how influence emanates from both levels. Domestic policy discourses can either strengthen or contest international discourses.

Programmes in a form of strategic documents in the arena of international forest governance take the form of "soft law", i.e. are non-legally binding. Nevertheless, they represent the set of ideas collectively adopted by the members having an informative value of the international forest political process preferences. At the same time, the programmes imply principles that are reflected in national orders (Faggin \& Behagel 2017). A (forest) policy program constitutes statements by (forest) stakeholders made in a social context concerning the utilization and/or protection of a forest (Krott 2005). The role domestic actors play in policy articulation and implementation is crucial for this research.

Several approaches to research on international and national forest policy level interactions have been recently developed. Bernstein \& Cashore (2012) propose a theoretical framework focusing on the transfer of principles from the international to the national level of forest policy. The approach takes into account the role of discourse and comprehensively covers the spectrum of the interaction of the global process with national forest policy. In their theory Bernstein \& Cashore (2012) define 4 pathways of influence flow, namely: 1. international rules, 2. international norms and discourses, 3 . the market, and 4. direct access to domestic political processes (Faggin \& Behagel 2017). Pülzl \& Mayer (2015) applied the systematic analysis of outputs on a quantitative and qualitative scale, followed by the impact and added value analysis to examine the interaction of the pan-European Forest Europe initiative with national forest policies. Two-way approach to analysis was developed by Börzel (2002) to describe top-down and bottom-up interactions between European and national level of policy. The approach was subsequently applied to the field of forest policy interaction research held by Aggestam \& Pülzl (2020). Authors consider Börzel's approach (2002) appropri- 
ate, as it takes into account both directions of the flow of influence and thus offers a comprehensive picture of the interaction. Börzel (2002) considers the European political process as a reciprocal relationship between political negotiations at domestic and European level. Domestic actors work with the national government to advance their interests to the European level. At European level, member states governments are working to pursue a policy that is in line with the demands of domestic actors and minimizes the adverse consequences for national policy. We consider the Börzel's two-way approach appropriate for examining national policy interaction with all levels of international forest governance, not only European one.

Uploading national policies is an effective way to minimize the costs of implementation, administrative and legal adaptation, while maximizing the benefits of integration, such as market opening and deregulation. There is a presumption the national governments will try to reduce the costs of implementation, and therefore try to enforce rules that correspond as closely as possible to their domestic political regulation. The degree of national interaction depends on: 1 . preferences and 2. capacity to act. On the basis of these criteria, the behaviour of states at the level of international cooperation can be evaluated and categorized into those who: 1 . actively promote their policies at the international level in order to minimize implementation costs 2 . block or postpone policies whose implementation is costly, or they are trying to get compensation for the costs incurred, 3. they are not active in promoting interests nor block decision-making processes but form tactical coalitions with one of the previous groups. Belonging to any of these categories depends on the economic development of the country and the level of domestic regulation. The national governments of the Member States are key players in both directions of influence flow, as they enter into the international decisionmaking processes while adapting the functioning of their institutions to regulations (Börzel 2002). In the case of forest policy, it is important to take into account a nonlegally binding nature of political processes. The costs of implementing their outputs are less relevant, as the implementation itself depends on the will at the level of national policy. Trying to avoid the costs of implementation is a "hard policy" phenomenon (Aggestam \& Pülzl 2020). The motivation of countries to actively participate in the creation of non-binding policy principles in the forestry sector may be the level of environmental regulation and tradition of forest policy in the country, or the effort to create the rules of current forest "soft policy" with a view to possible transformation to "hard policy" in the future.

\section{International forest political processes}

Consistent with the nature of forest policy governance arrangements (Rayner \& Howlett 2009; Mwangi \& Wardell 2012; Giessen \& Buttoud 2014; Arts et al. 2010) geopolitical scope criterion is applied to primarily divide forest policy initiatives in terms of the geographical affiliation and the target area of political interest, to 1. global, 2. supraregional and 3. sub-regional level (Šálka et al. 2017). The most significant ongoing initiatives focusing explicitly on forests, and at the same time being relevant from a perspective of applied research in European countries, are: 1. global level United Nations Forum on Forests, 2. supraregional level Ministerial Conferences on Forests (Forest Europe) and 3. sub-regional forestfocused processes under the EU.

The forest political processes are analysed through adapted PAA dimensions at each defined level. The information about processes and their steering mechanisms are based on literature review, including scientific papers, books, and studies available in databases, e.g. Scopus, WoS. The results of analysis are summarized in the Table 1.

Based on the dimensional analysis of processes, we define their common and different features as follows:

Common features of the processes are:

1. the governmental nature of the processes - each of them is attended by the governmental representatives of the individual member states as dominant actors,

2. state and non-state actors' participation - in addition to the state representatives, non-governmental organizations and other non-state actors are also involved in the processes (Bernstein 2011),

3. non-legally binding nature of outputs and strategic documents ("soft law"),

4. cross-sectoral management of forestry issues - crosssectorality is present mostly in processes ongoing under international organizations, the most within the EU, as forest policy is (over)ruled by various other policy sectors, as well as within the UNFF as the legally binding principles documents have been adopted in other areas of the environment that are directly related to forests (Convention on Biological Diversity, United Nations Convention on Climate Change, United Nations Convention to Combat Desertification). Forest Europe is a process sui generis in this respect, it emerged as a separate process focused exclusively on forest policy, yet it faces cross-sectoral issues as it takes over global principles adopted in other policy sectors and is also influenced by the European Union as one of the dominant players in this process (Kleinschmit \& Edwards 2013).

Distinguishing features of the processes are:

1. number of actors - related to the geopolitical scope, the largest number of actors enter the processes of global scope, the lowest number the process of sub-regional scope, the global process faces the most significant diversity of actors, and their interests,

2. level of participation of non-state actors - is the highest in Forest Europe, as the very setting of the operation of this initiative allows non-state actors to partici- 
pate or actively participate in some processes (Pülzl 2015), the lowest is in processes within the European Union, due to the political nature of this organization,

3. the impact of discourse - is the most noticeable at the global level, as it is one of important tools that shape the development of general principles of nature protection, taking into account differences in culture, thinking, ideas and level of interest in forestry that in this type of interaction differ significantly from one country to another; the global discourse is further reflected on the regional and national level, influencing political processes through the formation of ideas, opinions and the setting of social norms (Arts \& Buizer 2009),

4. bottom-up participation of member states - the greatest access to the formation of forest policy principles, i.e. uploading, is available to states as individual actors in processes under the EU. A large number of actors are involved in global processes, with groups of states having a more relevant influence in shap- ing global policy principles, and not individual states. There are few empirical examples of influencing the process from the perspective of member states as individual actors in the global forest policy process. One is the participation of the socio-economic coalition in Brazil as a host country of UNCED and its influence on the subsequent formation of its conclusions. Another example is the corruption crisis in Indonesia in the late 1990s, which affected the fight against corruption in forests around the world and led to the adoption of the "principle of good governance" as key to the international regime (Singer \& Giessen 2017). On the contrary, within the European Union some of individual states make intensive efforts to push forward their preferences (Börzel 2002). Under Forest Europe initiative, the most prominent access to principles formation are in the countries that are currently part of coordination committee, in which five states have membership on a rotation basis (Pülzl \& Mayer 2015).

Table 1. International forest political processes analysis through adapted Policy Arrangements Approach dimensions.

\begin{tabular}{|c|c|c|c|}
\hline Processes & GLOBAL & SUPRAREGIONAL & SUB-REGIONAL \\
\hline Name & United Nations Forum on Forests (UNFF) & Forest Europe & forest-focused processes under EU \\
\hline 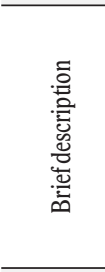 & $\begin{array}{l}\text { established in } 2000 \text { as the subsidiary body of the } \\
\text { United Nations Economic and Social Council; } \\
\text { objective: the management, conservation and } \\
\text { sustainable development of all types of forests; to } \\
\text { provide a platform for communication between } \\
\text { delegates and the adoption of common positions on } \\
\text { forest protection and the solution of global forestry } \\
\text { problems }\end{array}$ & $\begin{array}{l}\text { established in 1990; represents the brand name of } \\
\text { the Ministerial Conferences on the Protection of } \\
\text { Forests in Europe; objective: protection and sus- } \\
\text { tainable management of forests on the European } \\
\text { continent, provides a platform for political dialogue } \\
\text { between actors at regular intervals }\end{array}$ & $\begin{array}{l}\text { the founding treaties of the European Union do not } \\
\text { establish a common forest policy; nevertheless, for- } \\
\text { est policy is the subject of interest with regard to the } \\
\text { transfer of competencies and the political relevance } \\
\text { of this organization in the member countries }\end{array}$ \\
\hline 岕 & $\begin{array}{l}\text { universal membership; a large number of actors; } \\
\text { state actors: UN member states, groups of states } \\
\text { with a whole range of regulation and preference } \\
\text { setting; non-state actors: non-governmental and } \\
\text { intergovernmental organizations; global finance } \\
\text { actors: the World Bank }\end{array}$ & $\begin{array}{l}47 \text { signatories: } 46 \text { European countries and the } \\
\text { European Union; representatives of the ministries } \\
\text { of the member states, the European Union, observ- } \\
\text { ers: } 11 \text { non-European countries, non-governmental } \\
\text { organizations, forest owners, the professional } \\
\text { public, forestry actors }\end{array}$ & $\begin{array}{l}\text { European Commission, European Parliament, EU } \\
\text { Council; political representatives of the Member } \\
\text { States, interest groups/associations }\end{array}$ \\
\hline 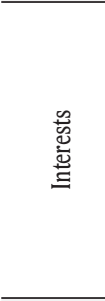 & $\begin{array}{l}\text { developed v. developing countries issue: developed } \\
\text { countries call for tropical forests sustainability, } \\
\text { developing countries ask for compensation; } \\
\text { legally-binding convention issue: Canada, some } \\
\text { EU countries in favor v. USA, Brazil and ACTO } \\
\text { countries, African countries, some EU countries, } \\
\text { NGOs opposing }\end{array}$ & $\begin{array}{l}\text { increased timber use v. deadwood and forest } \\
\text { set-asides for habitats and species conservation; } \\
\text { timber use for material production in forest-based } \\
\text { industries v. forest biomass use for bio-energy }\end{array}$ & $\begin{array}{l}\text { the sovereignty issue: minority of EU member } \\
\text { states (Greece, Italy, Spain, Portugal, France) will- } \\
\text { ing to widen EU competencies over forest policy } \\
\text { v. the UK, Slovakia and Sweden stating no wish } \\
\text { to cede competence in forestry to any organisa- } \\
\text { tion; nature conservation v. forest production as } \\
\text { key forest functions issue; Austria and Poland as } \\
\text { anomalies, having either strong forest sector as well } \\
\text { as conservation focus }\end{array}$ \\
\hline 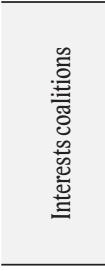 & $\begin{array}{l}\text { developing countries, developed countries, USA, } \\
\text { EU member states, states with tropical forests, } \\
\text { NGOs }\end{array}$ & $\begin{array}{l}\text { salient conflict in European countries between de- } \\
\text { mands for timber production on the one hand, and } \\
\text { energy wood production, biodiversity conservation } \\
\text { and climate protection on the other }\end{array}$ & $\begin{array}{l}\text { coalitions formed at the EU level are not as closely } \\
\text { interlinked and dominant as there is a lack of a } \\
\text { longer tradition of coordinated action and socializa- } \\
\text { tion within the community of forestry experts; po- } \\
\text { litical interest groups often emerge only in response } \\
\text { to a specific problem; associations formed within } \\
\text { the EU forestry sector are more or less forums of } \\
\text { national interest groups }\end{array}$ \\
\hline 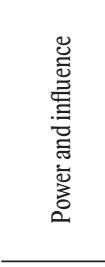 & $\begin{array}{l}\text { groups of states rather than individual states } \\
\text { have more relevant influence based on common } \\
\text { interests; government officials actively involved } \\
\text { in policy-making, while NGOs have limitations in } \\
\text { time and content of formal contributions; NGOs } \\
\text { operate through direct action - through capacity } \\
\text { building, technological and educational support, as } \\
\text { well as through discourse }\end{array}$ & $\begin{array}{l}\text { experts level meetings: participants (representa- } \\
\text { tives of ministries, observers, scientific community) } \\
\text { have a mandate to take decisions on the fulfillment } \\
\text { of ministerial commitments and prepare docu- } \\
\text { ments for the next ministerial conference, this level } \\
\text { of cooperation is considered the main decision- } \\
\text { making body }\end{array}$ & $\begin{array}{l}\text { forestry is a subject to the principle of subsidiarity: } \\
\text { the principles of forest management are the exclu- } \\
\text { sive competence of the Member States; the forestry } \\
\text { sector is overwhelmed by other sectors, political } \\
\text { representatives of the Member States and actors } \\
\text { from non-forestry sectors, legal action on forests is } \\
\text { mostly taken in non-forestry policy arenas }\end{array}$ \\
\hline
\end{tabular}




\begin{tabular}{|c|c|c|}
\hline Processes & GLOBAL & SUPRAREGIONAL \\
\hline 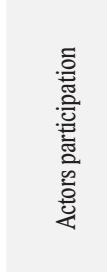 & $\begin{array}{l}\text { representatives of states, mainly in the form of } \\
\text { coalitions; the annual meeting is attended by } \\
\text { government representatives of the member states, } \\
\text { regional international forestry organizations, non- } \\
\text { governmental organizations, etc. are also invited; } \\
\text { the central actors in the decision-making process } \\
\text { are the Member States, and the participation rights } \\
\text { of observers are minimal }\end{array}$ & $\begin{array}{l}\text { government representatives from ministries; } \\
\text { a high degree of participation of non-state forestry } \\
\text { actors actively involved in the processes; Forest Eu } \\
\text { rope gives observers the right to actively participat } \\
\text { in decision-making processes: expert level meeting } \\
\text { are attended by representatives of signatories, } \\
\text { representatives of observers, the scientific com- } \\
\text { munity, etc. }\end{array}$ \\
\hline
\end{tabular}

UNFF meetings once a year; the working group prepares the program of meetings for 4 years, it includes a presentation of the state of contribution to the fulfillment of strategic goals by nation states, which is on a voluntary basis ministerial conferences, expert level meetings, round table meetings, general coordinating committee; political dialogue between actors taking place at regular intervals: 1 . at the highest level 2. experts level meetings (see below), 3. round table Directorate-General for Industry (wood industry), meetings providing a platform for the exchange the Directorate-General for the Environment of views and information on the implementation of commitments; the managing authority is the general coordinating committee consisting of 5 member countries, represented on a rotating basis, presiding country sets up a so-called Liasion Unit, which acts as the secretariat mission, EU Council Forestry Working Group, Standing Forestry Committee; within the European Commission, the Directorate-General for Agri(nature protection, biodiversity, climate change) and others (Directorate-General for Energy; for Research; for Development); the EU Council

Forestry Working Group serves as a forum for communication between the European Commission and the Member States in the forestry, and it deals non-forestry actors are actively involved in forestry policy-making: due to the absence of legally binding regulation, and to the limited political power of the forestry sector in some of the member states, especially in southern Europe; the number of forest objectives is rising, but there is a lack of coherence and coordination; forest policy actors in the $\mathrm{EU}$ face challenges posed by cross-sectoral and multi-level governance, as well as conflicting goals between actors; several directives demand public participation in decision-making processes

Directorates-General of the European Comwith international issues

the $\mathrm{EU}$ is generally characterized by a higher

different states groups as well as NGOs interests weaken decision power of the organization

the most important decisions are taken at the level of expert meetings, which are governed by informal common rules

degree of relevance for national policies of member states, due to the high degree of transfer of competences from national to Community level, this trend does not apply for forestry policy sector

official statements on the webpage, especially DC AGRI and DG ENVIRO; from January to April 2021 debate on the new $E U$ forest strategy is ongoing addressed to all citizens and organisations, as the Commission is looking for input from a wide range of stakeholders institutionalizing the influence of NGOs and expanding their participation in the political process

the non-legally binding Strategic Plan for Forests; politically binding on States, establishes a political obligation for States to comply with it, but not legally binding- not enforceable under the principles of international law;

it contains 6 basic goals for the world's forests and 26 operational goals, the fulfillment of which is universal and voluntary, with the deadline in 2030

PR policy in forestry, connection to the general public through the homepage, publications available to the public and social networks

the non-legally binding European Forests 2020

document adopted at the Oslo Ministerial Confer- the non-legally binding EU Forestry Strategy, ence in 2011; defines specific and measurable targets for sustainable forest management at both international and national levels; two categories of set goals are:

1. Strategic objectives for European forests, 2. European targets untill 2020 (operational targets) established by the Council Regulation of 15 December 1998 on the EU Forestry Strategy, it sets out general principles for putting sustainable forest management into practice, offers a framework for forest-related activities; links EU policies with Member States' forest policies

the most significant outcomes having an impact on an example of uploading is the pressure from the way in which the objectives of the UNFF Strate- the national forest policy include: 1 . the defining gic Plan are to be met, the conditions and funding of the concept of sustainable forest management have been set out in a general and ambiguous included in the legislation of several European manner, with Member States being skeptical about countries, 2. the creation of a pan-European meeting them; so-called The World Forest Facilitation Network serves to pool individual financial resources, namely global, regional, national, public or private, and resources from other joint environmental initiatives framework of indicators and criteria for sustainab
development, 3. the establishment of a common framework of national forest programmes in the European context leading to the creation, implementation or supplement of the national forest programmes in many European countries countries with advanced national forestry policies to set the legislative framework for the development of forestry policy in the EU; Finland, Sweden and Austria joined the EU in 1995 and initiated a move towards a common framework for forest policy, the pressure from these countries led to the adoption of a Thomas report in the form of a European Parliament resolution implying an obligation for the European Commission to issue legislative intention of the so-called European Forestry Strategy

(Arts et al. 2010); (Andong \& Ongolo 2019); (Dimitrov et al. 2007); (Faggin \& Behagel 2016); (Henry \& Tysiachniouk 2018); (Humphreys 2006), (Park (Edwards \& Kleinschmit 2013); (Linser et al.

Literature \& Lee 2019); (Pülzl 2015); (Pülzl \& Dominguez 2013); (Rayner et al. 2010); (Singer \& Giessen 2017); (Sotirov et al. 2020); (Šálka, Dobšinská, 2020); (Pülzl 2015); (Pülzl \& Mayer 2015); (Sotirov, Arts 2018); (Surubaru 2017)

(Aggestam \& Pülzl 2020); (Börzel 2002); (Čerkala 2011); (Edwards \& Kleinschmit 2013); (Paraskevopoulos, Getimis, Rees 2006); (Hogl 2000); (Konôpka et al. 2010); (Pülzl \& Hogl 2013); (Sotirov \& Storch 2018); (Šulek 2014) 


\section{Further application of framework}

Suggested theoretical and methodological framework is based on adapted PAA. The approach per se defines dimensions of political process, thus propose foundation for comprehensive desciption of forest policy initiatives. Moreover, the dimension of level interactions was added to the PAA, as we consider the information concerning the extent to which domestic policy is active in uploading the preferences, as well as the extent to which outputs from international level are transferred to the national, highly beneficial to research results. Further, we analysed three international forest policy initiatives through adapted PAA dimensions. The UNFF is global initiative with universal membership focusing explicitly on forests. The supraregional Forest Europe is the only one of its kind forest-focused initiative within European continent. Although there is no explicit focus on forests, we have decided to include the EU in our analysis as the most influential political process in the European region. The framework can be subsequently applied for research in different European countries, considering their similarities and diferencies in forestry history and current forest policy.

Domestic forest policy stakeholders' perceptions analysis will be provided through semi-structured interviews. Information will be obtained from actors, in our case key domestic stakeholders from forestry through targeted questions that will be asked to the respondent "face to face" (Meuser \& Nagel 1991). In a structured interview the questions will be worded precisely and in a certain order. Stakeholders will be first selected by the authors using stakeholder analysis and then using the snowball method, which can also lead to gathering new impulses, information and issues arising.

The international forest policy research will be strengthened by strategic documents analysis. We consider the analytical strength of the strategic documents analysis in providing primary information on the level of international forest policy "soft law" outputs translations in selected countries. The potential weakness may be reflected in an uncertain distinction in a matter of which principles are the result of processes and which would be part of domestic forest policy regardless of international governance regulation.

The analysis of domestic forestry stakeholders' attitudes will lead to useful information on the awareness of national actors about the ongoing processes, the degree of their participation and the perceived relevance of processes directly on the domestic forest policy scene. The questions must be worded preciously to have the highest informative value. Attitudes of domestic actors towards international forest political processes may be also relevant for ongoing tries of transformation from non-legally to the legally-binding regulation of the international forest policy principles. The uniqueness of the approach is the focus on domestic stakeholders' perceptions of international forest policy processes in conditions of domestic forest policy. However, using semi-structured interviews with key domestic forest policy representatives as the main research method limits the outputs to willingness, awareness and sincerity of respondents. We assume this weakness of the research to be balanced by international and national strategic forest policy documents analysis. The research results will serve as a basis for subsequent comparative analysis between countries.

\section{Acknowledgement}

This publication is the result of the projects implementation: FOMON - ITMS 313011V465, supported by the Operational Programme Integrated Infrastructure (OPII) funded by the ERDF and the IPA 6/2021.

\section{References}

Aggestam, F., Pülzl, H., 2020: Downloading Europe: A regional comparison in the uptake of the EU Forest Action Plan. Sustainability, 12:1-14.

Andong, S., Ongolo, S., 2019: From global forest governance to domestic politics: The European forest policy reforms in Cameroon. Forest Policy and Economics, $111 \mathrm{p}$.

Agrawal, A., Chhatre, A., Hardin, R., 2008: Changing governance of the world's forests. 320:1460-1462.

Arts, B., Buizer, M., 2009: Forests, discourses, institutions: A discoursive-institutional analysis of global forest governance. Forest Policy and Economics, 11:340-347.

Arts, B., Giessen, L., Visseren-Hamakers, I., 2013: International Forest policy and Europe: Four pathways of mutual influence. What Science Can Tell Us, 2:37-42.

Arts, B., Leroy, P., 2006: Institutional dynamics in environmental governance. Springer Netherlands, 294 p.

Arts, B., Leroy, P., van Tatenhove, J., 2006: Political modernisation and policy arrangements: a framework for understanding environmental policy change. Public Organization Review, 6:93-106.

Arts, B., Appelstrand, M., Kleinschmit, D., Pülzl, H., Visseren-Hamakers, I. et al., 2010. Discourses, actors and instruments in international forest governance. Embracing complexity: Meeting the challenges of international forest governance, p. 57-72.

Bache, I., Flinders, M., 2004: Multi-level Governance. New York, Oxford University Press Inc., 237 p.

Benčo, J., 2001: Metodológia vedeckého výskumu. Bratislava, IRIS, $194 \mathrm{p}$.

Bernstein, S., Cashore, B., 2012: Complex global governance and domestic policies: four pathways of influence. International Affairs, 3:585-604. 
Börzel, T. A., 2002: Pace-Setting, Foot-Dragging and Fence-Sitting, member states responses to Europeanization. Journal of Common Market Studies, 40:193-214.

Cinar, K., 2018: Convergence in public sector upsizing/ downsizing: An analysis of post-communist countries and the EU. International journal of emerging and transition economies, 7:1-17.

Dryzek, J., 1997: The politics of the Earth: environmental discourses. Oxford, Oxford University Press, 270 p.

Dimitrov, R. S., 2005: Hostage to norms: States, institutions and global forest politics. Global environmental politics, 5:1-22.

Dimitrov, R. S., Sprinz, D. F., Diguisto, G. M., Kelle, A., 2007: International nonregimes: a research agenda. International studies review, 9:230-258.

Edwards, P., Kleinschmit, D., 2013: Towards a European forest policy: Conflicting courses. Forest Policy and Economics, 33:87-93.

Faggin, J. M., Behagel, J. H., 2017: Translating Sustainable Forest Management from the global to the domestic sphere: The case of Brazil. Forest Policy and Economics, 85:22-31.

FAO 2020. The State of the World's Forests 2020: Forests, biodiversity and people. Rome, FAO and UNEP, $188 \mathrm{p}$.

Giessen, L., 2012: Reviewing empirical explanations of policy change: Options for its analysis and future fields of research. Allgemeine Forst Und Jagdzeitung, $182 \mathrm{p}$.

Giessen, L., 2013: Reviewing the main characteristics of the international forest regime complex and partial explanations for its fragmentation. International Forestry Review, 15:60-70.

Giessen, L., Buttoud, G., 2014: Defining and Assesssing Forest Governance. Forest Policy and Economics, 49:1-3.

Giessen, L., Kleinschmit, D., Böcher, 2009: Between power and legitimacy- discourse and expertise in forest and environmental governance. Forest policy and economics, 11:452-453.

Glück, P., Angelsen, A., Appelstrand, M., AssembleMvondo, S., Auld, G. et al., 2010: Core components of the international forest regime complex. In Overcoming to challenges to integration: embracing complexity in forest policy design through multi-level governance. A global assessment report. IUFRO, Vienna, 28:37-55.

Hajer, M., 1995: The politics of environemntal discourse, ecological modernization and the policy process. Oxford, Clarendon Press, 332 p.

Hajer, M., 2003: Policy without polity? Policy analysis and the institutional void. Policy Sciences, 36:175195.

Hall, P.A., 1996: Political Science and the three new institutionalisms. Political Studies, p. 936-957.
Hall, P. A., 2006: Systematic process analysis: when and how to use it. European Management Review, p. 24-31.

Henry, L. A., Tysiachniouk, M., 2018: The uneven response to global environmental governance: Russia's contentious politics of forest certification. Forest Policy and Economics, 90:97-105.

Hogl, K., 1999: The Austrian domestic forest policy community in change? Impacts of the globalisation and Europeanisation of forest politics. Forest Policy and Economics, p. 3-13.

Humphreys, D., 2003: Life protective or carcinogenic challenge?: Global forests governance under advanced capitalism. Global environmental politics 3:40-55.

Humphreys, D., 2009: Discourse as ideology: Neoliberalism and the limits of international forest policy. Forest policy and economics, 11:319-325.

Howlett, M., Rayner, J., Goehler, D., Heidbreder, E., Perron-Welch, F., Rukundo, O. et al., 2010: Overcoming to challenges to integration: embracing complexity in forest policy design through multi-level governance. A global assessment report. IUFRO, Vienna, 28:93-110.

Kleinschmit, D., Böcher, M., Giessen, L., 2009: Discourse and expertise in forest and environmental governance. Forest policy and economics 11:309-312.

Konôpka, J. et al., 2010: Príručka vlastníka a obhospodarovatel'a lesa. Zvolen, NLC, $212 \mathrm{p}$.

Krasner, S. D., 1982: Structural causes and regime consequences: Regimes as intervening variables. International organization 36:185-205.

Krott, M., Bader, A., Schusser, C., Devkota, R., Maryudi, A., Giessen, L., Aurenhammer, H., 2013: Actor-centred power: The driving force in decentralised community based forest governance. Forest Policy and Economics, p. 1-9.

Liefferink, D., 2006: The dynamics of policy arrangements: turning round the tetrahedron. In: Arts, B., Leroy, P. (eds) Institutional dynamics in environmental governance. Springer, Dodrecht, p. 45-68.

Logmani, J., Krott, M., Lecyk, M. T., Giessen, L., 2017: Customizing elements of the International Forest Regime Complex in Poland? Non-implementation of a National Forest Programme and redefined transposition of NATURA 2000 in Bialowieza Forest. Forest Policy and Economics, 74:81-90.

Marcos-Martinez, R., Bryan, B. A., Schwabe, K. A., Connor, J. D., Law, E. A., Nolan, M., Sánchez, J. J., 2019: Projected social costs of $\mathrm{CO}_{2}$ emissions from forest losses far exceed the sequestration benefits of forest gains under global change. Ecosystem Services, 37:1-10.

Maier, C., Lindner, T., Winkel, G., 2014: Stakeholders' perceptions of participation in forest policy: A case study from Baden-Württemberg. Land Use Policy, 39:166-176. 
Meuser, M., Nagel, U., 1991: Experteninterviews - vielfach erprobt, wenig bedacht, Ein Beitrag qualitativen Methodensdiskussion, In: Garz, D., Kraimer, K. (ed.): Qualitativ-empirische Sozialforschung: Konzepte, Methoden, Analysen, Westdeutscher Verlag, Opladen, p. 441-471.

Mwangi, E., Wardell, A., 2012: Multi-level governance of forest resources. International journal of the Commons, 6/2:79-103.

Paraskevopoulos, CH. J., Getimis, P., Rees, N., 2006: Adapting to EU Multi-Level Governance. Hampshire: Ashgate Publishing Limited, 301 p.

Park, M. S., 2015: Inter-Korean forest cooperation 1998 2012:A policy arrangement approach. Sustainability, 7:5241-5259.

Park, M. S., Lee, H., 2019: Accountability and reciprocal interests of bilateral forest cooperation under the global forest regime. Forest Policy and Economics, 101:32-44.

Pülzl, H., Hogl, K., 2013: Forest governance in Europe. What Science Can Tell Us, 2:11-17.

Pülzl, H., Mayer, P., 2015: Assessment of the achievements and added value of the Forest Europe Process. Technical report, $17 \mathrm{p}$.

Rayner, J., Howlett, M., 2009: Introduction: Understanding integrated policy strategies and their evolution. Policy and society, p. 99-109.

Rayner, J., Buck, A., Katila, P., 2010: Embracing complexity: Meeting the challenges of international forest governance. A global assessment report. IUFRO, Vienna, 28:172.

Sabatier, P., 1988: An Advocacy Coalition Framework of policy change and the role of policy learning therein. Policy Sciences, 21:128-168.

Scharpf, F. W., 2000: Institutions in comparative policy research. Max Planck institute for the study of societies, p. 1-24.

Schneider, V., 2009: Governance and complexity. Oxford university press, p. 129-142.

Schusser, C., Krott, M., Movuh, M. C. Y., Logmani, J., Devkota, R. R., Maryudi, A. et al., 2015: Powerful stakeholders as drivers of community forestry Results of an international study. Forest policy and Economics, 58:92-101.

Schusser, C., Krott, M., Movuh, M., C., Y., Logmani, J., Devkota, R. R., Maryudi, A., Salla, M., 2016: Comparing Community Forestry Actors in Cameroon, Indonesia, Namibia, Nepal and Germany. Policy Economics, 68:81-87.
Singer, B., Giessen, L., 2017: Towards a donut regime? Domestic actors, climatization, and the hollowingout of the international forests regime in Anthropocene. Forest Policy and Economics, 79:69-79.

Smolík, J., 2014: Úvod do studia mezinárodních vztahů. Praha, Grada Publishing, 232 p.

Sotirov, M., Arts, B., 2018: Integrated forest governance in Europe: An introduction to the special issue on forest policy integration and integrated forest management. Land use policy, 79:960-967.

Sotirov, M., Storch, S., 2018: Resilience through policy integration in Europe? Domestic forest policy changes as response to absorb pressure to integrate biodiversity conservation, bioenergy use and climate protection in France, Germany, the Netherlands and Sweden. Land use policy, 79:977-989.

Sotirov, M., Pokorny, B., Kleinschmit, D., Kanowski, P., 2020: International Forest Governance and Policy: Institutional Architecture and Pathways of Influence in Global Sustainability. Sustainability, 12:1-25.

Surubaru, N. C., 2017: Revisiting the role of domestic politics: politicisation and European Cohesion Policy performance in Central and Eastern Europe. East European Politics, 33:106-125.

Šálka, J., 2006: Analýza verejnej politiky v lesníctve. Zvolen, Technická univerzita vo Zvolene, 63 p.

Šálka, J., Dobšinská, Z., Sarvašová, Z., Štěrbová, M., Paluš, H., 2017: Lesnícka politika. Zvolen, Vydavatel'stvo Technickej univerzity vo Zvolene, $275 \mathrm{p}$.

Weber, N., 2012: Reflections on theories in forest policy: Testing, combining or building? Forest Policy and Economics, 16:102-108.

Wolfslehner, B., Lindner, M., Nabuurs, G. J., 2013: European forests: setting the context. What science can tell us, p. 19-28.

Wolfslehner, B., Pülzl, H., Kleisnchmit, D., Aggestam, F., Winkel, G., Candel, J. et al., 2020: European forest governance post-2020. From science to policy, $52 \mathrm{p}$.

Wydra, D., 2013: The legal context of European forest policy-making. What science can tell us, p. 29-36.

Yin, R. K., 2009: Case study research: Design and methods (4th ed.). Thousand Oaks, CA: SAGE Publications. 